\title{
Autocracy, Institutional Constraints and Land Expropriation: A Conceptual Analysis of Land Redistribution in Zimbabwe
}

\author{
DUBE MAKUWERERE Langton \\ School of Government, Sun Yat Sen University \\ No. 135 Xingang Xi Road \\ Haizhu District, Guangzhou, China
}

Received: May 17, 2020 Accepted: June 10, 2020 Online published: June 24, 2020

doi:10.5296/jpag.v10i2.17040～URL: https://doi.org/10.5296/jpag.v10i2.17040

\begin{abstract}
Using the Zimbabwean case, this article explores the assertion that autocracies are better placed than democracies in land redistribution because of lower institutional constraints and concentration of power which makes policy implementation easier. This is rightly so, because such political systems have the notoriety of neutralizing or eliminating the veto gauntlet which is normally strengthened by institutional autonomy. Extant literature on land reform continues to grapple with overarching questions as to why countries redistribute land, relating to the type of conditions that incubate the need for reform and the political purpose that redistribution serve in this world. Equally important, is the need to interrogate the real beneficiaries of land reform. The study notes that in the post-Cold War globalized era of 'fractured sovereignty', redistribution from above remains attractive despite its protracted nature. However, against a post-colonial settler land discourse that memorializes race, privilege, dispossession, and restitution, the article evinces that land redistribution is tainted by elitism, clientelism, and partisanship which eventually distort its structural transformative power.
\end{abstract}

Keywords: autocracy, land reform, expropriation, redistribution, Zimbabwe

\section{Introduction}

The land is a productive agency for marginalized cohorts who are heavily dependent on agriculture as their central avenue for household income (Lipton, 2009). This resource is multi-faceted whose agency involves, but is not limited to, social insurance, employment, and sustenance, surety against old age and infirmity and also as security for future generations. 
Much of the developing south shares a common history of colonial modernity, in which land dispossession, expropriation, and alienation is a central leitmotif. This resulted in structural inequalities between the races distorting whatever natural process of primitive accumulation that could have taken place. Land redistribution has restitutive and affirmative action capital which makes it an attractive launching pad for structural transformation of rural livelihoods (Thiesenhusen, 1989) and the significant 'reordering of social relationships' (Huntington, 1968).

The article begins by giving a literature review of theoretical concepts surrounding the linkage between regime type or governance systems and land redistribution. Using examples from across the globe and chiefly from Latin America, the paper proceeds to highlight Albertus' theory which propounds that land reform is more likely to occur under a political system that has a higher concentration of power in a top-down identity which tends to stifle institutional autonomy and its oversight role and veto capabilities. The article proceeds to briefly explore the conditions stated by Albertus (2015) that incentivize land redistribution against the complexities emanating from the transitional arrangement that brought about independence in Zimbabwe. The discussion goes on to note that this type of redistribution from above whereby institutional autonomy and veto capability is reined in is a potential minefield in the post-Cold War era of globalized political economics characterized by a kind of 'fractured sovereignty' between the state and myriad international actors whose interests hem or stymie the redistributive agenda The article then concludes by arguing that Albertus' theory of redistribution from the top, especially in a post-colonial African state, can be highly partisan and elitist which severely undercuts its ability to benefit most of the poor. Pursuant therefore, redistribution will serve political ends and patronage purposes. The true spirit of affirmative action is diluted in favour of elite embourgeoisement or accumulation which further heightens contestations.

Utilizing extant literature, analysis of comparative literature and various secondary source s of data the article applies a desktop survey to situate Zimbabwe's land redistribution discourse within the theoretical contours set out by Albertus (2015). The nuances defining the Zimbabwean land redistribution trajectory such as its revolutionary and combative character, top down and dirigiste identity and most importantly the attendant racial undertones did not require a straightjacket application of Albertus theory. Rather, the article utilized a purposive sampling approach to the comparisons and drew lessons from the land redistribution experiences in Latin America between 1950 and 1990 and also from countries like the Phillipines, Iran under the Shah, Egypt under Gamal Abdel Nasser and even Tanzania under Julius Mwalimu Nyerere. All these experiences strengthened the notion that authoritarian or highly centralized regimes are better placed to effect wholesale redistribution of land in a top down dirigiste character that crowds out the veto gauntlet. Equally, the study also juxtaposed those experiences with the negligible inertia that land redistribution continues to face in countries like Namibia and South Africa which have a rich settler colonial history just like Zimbabwe but wherein land redistribution has been stifled by the veto gauntlet 


\subsection{Significance of the Study}

This paper provides an analogy of Zimbabwe's land reform narrative (expropriation and redistribution) and applies Albertus's theory that autocracies are better placed to serve redistributive policies than democracies to explain political underpinnings of redistribution, the political purposes it serves and lastly but not least the relevancy of land reform in today's world. Rooted in colonial settler history, the narrative that redistribution serves to redress colonial injustices and to structurally transform rural livelihoods is cast in stone; however, it has been challenged as an economically poor and haphazardly implemented policy wittingly designed for political mileage.

Taking cognizance of the various types of land reform, the article attempts to analyze the relationship between land redistribution and regime type in a bid to provide some insights into the nuances that characterize the Zimbabwean trajectory. Therefore drawing from international experiences, the article argues that while it is desirable that the discourse of land redistribution should be subjected to the rigor of a 'protected consultation', the historical contradictions of post-colonial settler states like Zimbabwe promotes redistribution that is championed by the state. The study is not an exercise in confirming Albertus assertion concerning the Zimbabwean experience, rather the article proposes that in post-colonial settler Africa, born out of pacted transitions that served to protect the interests of white capital, wherein the control of land and other productive sectors of the economy remain deeply conflated with race, exploitation, restitution and ultimately economic emancipation, redistribution has to be engineered from above if a significant transfer of resource ownership is to be realized.

\subsection{Theoretical Background}

Land reform is a broad concept covering a motley collection of policies that together constitute agrarian land reform. These include, for example, the provision of credits, availing of input schemes supporting infrastructure and marketing assistance (Tuma, 1965; Deininger, 2003). It also covers land expropriation and redistribution, land colonization programs, land titling, tenure reforms and also the generation of private land markets among others (Albertus, 2015). However, policies that necessitate the physical transfer of land ownership (in this case land expropriation and redistribution) hold a very critical position in the field of land reform in the South. These policies have a higher restitutive capital hence a significant chunk of land reform literature has delved so much into land transfer programs at the expense of other policies that form the body of land reform (Tai, 1974). Therefore, while acknowledging the broad discipline of land reform, this article zones in on land expropriation and redistribution because of its agency as the first major step in altering proprietorship. While in this article, the terms 'land reform' and land redistribution are used interchangeably, in essence, the primary focus is on land expropriation and redistribution.

Extant literature is inundated with propositions attempting to explain the political foundations and rationalities of land reform either as a means to the end or an end in itself. Some of the pertinent questions posed are: Why do governments engage in socially redistributive land reform? What are the incentives and motivations that drive the redistribution process? What 
are the political conditions that necessitate land redistribution? Who are the intended beneficiaries of land redistribution? The main contribution to this field emanates from the social conflict theory which propounds that democratic or pluralist polities are more likely to encourage the proliferation of affirmative action policies (Boix, 2003; Acemoglu and Robinson, 2006). The notion is that pluralistic regimes create space for the poorer cohorts to manoeuvre, exert pressure and extract concessions from the political economy, in the process narrowing the affluence gap between the rich and the poor (Albertus, 2015). Because in democracies, "all share in all things, in oligarchies the opposing practice prevails" (Aristotle, 1992), therefore democracies are redistributive.

Social conflict theory focuses on democratic transitions wherein the life span of a democratic regime is highly contingent on the level of inequality obtaining in a country (Albertus, 2015). Higher inequality, therefore, leads to more redistribution and if inequality is low, the opposite is true. Studies have however shown that redistribution is never high under democracies than autocracies Scheve and Stasavage, 2011). What passed for the empirical analysis is that higher levels of inequality and redistribution are not intimately related to democratic rule (Perrotti, 1996; Mulligan, et al, 2004; Iverson and Soskice, 2009).

This theory has been challenged in some quarters because of its inherent weaknesses and oversights. The argument is that elites everywhere wield so much power and versatility that allows them to hem and circumvent democratic institutions in a manner that hamstrings redistributive policies. Elites have in their arsenal some potent ammo like vote-buying and patronage which can factionalize and fractionalize potential power inherent in the grassroots (Ziblatt, 2009; Albertus 2015). Besides, the current state of land distribution in South America casts doubt on the applicability of this theory. Democratic consolidation has remarkably strengthened after an era of dictatorship and coups by military juntas in the mid $20^{\text {th }}$ century but the inertia of land expropriation and redistribution has been piecemeal (Albertus, 2015).

Also, autocracies are characterized by dearth of informal institutions and commitment mechanisms which are critical factors that protect the sanctity and inviolability of property rights. In the same vein, institutional checks and balances with the potential to block redistribution are repressed at best or nonexistent at worst (Olsson, 1993; North and Weingast, 1989). On the contrary, democracies are fraught with institutional hurdles and the 'veto gauntlet' which makes pluralistic politics and democratic rule very incompatible with land redistribution (Boix, 2003; Huntington, 1968). Actually, according to Tai (1974), there is a higher probability of land reform being implemented when power is limited to a single political formation or a small group of individuals.

Lapp (2004) contends that land reform can still happen in a democracy because an open political space broadens participation hence land reform can be a function of political parties jostling for voters. Redistribution can also be as a result of the coming to power of revolutionary nationalist movements in countries where colonial settlerism was the dominant economic logic of accumulation (Paige, 1975) or it may be a consequence of pressure from a newly enfranchised peasantry following a revolution or protracted struggle (Thiesehusen, 
1995). The two contributions by Paige (1975) and Thiesenhusen (1995) apply directly to Zimbabwe wherein on the one hand, land reform was championed by a nationalist government and on the other hand, the inertia and nuances of the land discourse was conditioned by the pacted transition that severely stifled and replaced expropriation with negotiated land redistribution during the first ten years of independence.

\section{Redistribution and Autocracy}

According to Albertus, $(2011 ; 2015)$, there is a correlation between autocracy and redistribution. There is extensive literature that affirms that resource redistribution or policy changes, in general, are difficult to effect under democracies because of their inbuilt heterogeneous institutions with checks and balances that can veto policies (Tsebelis, 2002; Snyder and Samuels, 2004). In addition, landed elites possess the ability to hedge their interests under a democratic mask through favourable pacts during transitions that can safeguard their interests (Karl, 1990). It follows therefore, that lower or fewer institutional constraints mostly common under autocracies or hybrid regimes are essential for redistribution to occur. According to Tai (1974), redistribution is also likely to be carried out in a one-party political system or where political power revolves around a small clique of leaders. Most single-party regimes bank on a strong state apparatus whose coordination is critical towards implementation, even though single-party regimes are 'straitjackets' with fewer institutional constraints. Conversely, redistribution may still happen under democracies however in majoritarian systems in which institutional autonomy can be hamstrung or diluted by populist tendencies (Meltzer and Richard, 1981). In the same vein, redistribution can also occur under a democratic dispensation to the extent that the landed elites allow as long as it does not threaten landed interests.

The execution of land expropriation and redistribution is conditioned by the presence of incentives and the capacity of the government to implement. In his seminal contribution to land reform, Michael Albertus (2015) propounded two critical factors that incubate the necessary conditions for redistribution to take place. Firstly, that land redistribution requires a coalitional split between the landed elites, gentry or the large landholders and the ruling political elites. Such a coalitional split provides the incentives for the latter to seek to fractionalize the combined power inherent in that cohort.

Secondly, redistribution requires a higher and sustained level of institutional cooperation and unity of purpose. It follows therefore that low institutional constraints are an indispensable requirement for effective implementation of land redistribution. Institutional cooperation should span across the traditional three arms of government to include the bureaucracy. The executive branch provides the political will and ideological creed to reform, while the judiciary provides the legal foundation and the legislature sanitizes the whole process by providing due process, oversight, legal formulation and also funding which is very important. The bureaucracy is one vital part of the puzzle because of its implementation through its line ministries and various organs.

Albertus's theory also states the political purpose that redistribution serves for the ruling elite ranging from the neutralization of threat from landed elites to the appeasement of critical 
grassroots constituencies whose resistance or support to the 'establishment' can raise the political costs of ruling and undercut political stability (Albertus, 2015; Boix, 2003; Acemoglu and Robinson, 2006). Redistribution can also be a populist measure, the low hanging fruits that allow political elites to garner political capital and legitimacy (Levine, 1998), an agency that cultivates and strengthens peasant dependencies and patronage alliances (Albertus, 2015).

\subsection{Autocracy and Redistribution: The Case of Latin America}

The land has remained a very important agency of structural transformation in Latin America against the region's colonial background and the resultant inequalities. In a region where colonialism was entrenched through proprietorship of the land resource under such systems as the encomienda- hacienda system or the latifundio-minifundio systems of land dispossession and labour peonage, land redistribution remained a legitimate avenue for social articulation. As a fixed illiquid asset whose importance feeds, wealth, power, pride and status, landholdings heighten prospects for redistribution in a society characterized by a wide affluence gap between the rich and the poor (Boix, 2003). Using data not exclusively based on land but generally, resource redistribution, Albertus (2011), concluded that redistribution has been greatest under periods of autocratic rule. In his seminal study of all Latin American countries covering the period 1950-1990, Albertus (2011) noted that approximately 140 million hectares of land were expropriated and redistributed. On the one hand, countries like Bolivia, Chile, Cuba, Guatemala, Mexico, Nicaragua, El Salvador, Dominican Republic, Brazil, and Peru scored higher rates of land redistribution under autocracy. On the other hand, countries like Venezuela, Paraguay, Uruguay, and Argentina experienced relatively lower rates of redistribution under autocratic periods.

Accordingly, Cuba recorded the highest redistribution per country rate of $73 \%$ of the total land area while Mexico expropriated 54 million hectares and Argentina, Paraguay, Uruguay, and Venezuela all recording less than 5\% of arable land (Albertus, 2011). The Bolivarian and Cuban revolutions of 1952 and 1959 respectively all resulted in extensive expropriation of land under systems deemed autocratic while the post-1961 coup in the Dominican Republic resulted in the expropriation and redistribution of former dictator Rafael Trujillo's extensive land holdings (Albertus, 2011; 2015). According to Albertus (2011), there were a total of 359 country-years of democracy compared to 401 country-years of autocracy between 1950 and 1990, wherein the average yearly distribution was $1,4 \%$ of arable land with democracies having a score of $0.9 \%$ against $1,9 \%$ for autocracies. However, Venezuela's case provides a complicated scenario in which redistribution has been negligible under democracy not because of the democratic gridlock but rather as a result of elites who accepted democracy on their terms which gave them leverage to block redistribution (Albertus, 2011). The elites accept democracy as long as their interests are protected in this instance.

Besides Latin America, the assertion that autocracy is more amenable with redistribution also finds expression in redistribution under Gamal Abdel Nasser in Egypt in the 1960s, redistribution under the Shah in Iran beginning in 1963 and most notable in the Philippines under Ferdinand Marcos starting from 1971 (Powelson and Stock, 1990). Other notable cases 
buttressing redistribution under autocracy, hybrid, and single party or authoritarian regimes also include Nyerere's Ujamaa collectivization of rural land in Tanzania, the nationalization of rural land in Ethiopia and Zambia among others (Albertus, 2011).

\section{Conditions and Incentives for Redistribution}

The proposition that autocracies have a higher degree of land redistribution is not arbitrary because some autocracies do not redistribute resources therefore there is a need to account for that gap. According to Albertus (2015), the key factor that determines whether the ruling political elite will undercut the landed elite to institute any form of land redistribution is the level of coalitional overlap between the ruling elite and their initial support base or between the ruling elites and the landed elites. According to Albertus, it is from these coalitional dynamics that elite splits are created that create incentives promoting redistribution. There is a need to distinguish between, on the one hand, the initial support coalition which refers to the launching organization that formed the foundation for the ruling coalition to access power and on the other hand, the governing coalition which may be borne out of governing exigencies. This governing coalition guarantees power to the ruling elites and its composition may differ from that of the initial organization (Haber, 2006).

When membership of the ruling elite's initial support coalition is made up of the landed elite or when the ruling elite is highly dependent on the landed elite for financial or logistical support, redistribution is highly constrained. Conversely when the initial support coalition is not made up of the landed elites, depended on them or allied to them, the incentives for redistribution becomes visible (Albertus, 2015). In Zimbabwe, the initial support coalition was forged between the revolutionary movements and the peasants along Marxist/ Leninist/ Maoist lines wherein effective revolutionary execution, while highly contingent on the military realm, was also underpinned by a symbiotic relationship between the cadres and the masses. The creed that the 'peasants are the water and the soldiers are the fish' clearly espouses the sacral nature of the relationship. However, independence brought with it some dynamic governing exigencies through the unveiling of a new set of actors which greatly transformed the governing coalition as opposed to the initial support coalition which unravelled the distinction that Harber (2006) propounded. These new actors forming the governing coalition included introverted and extroverted white capital interests undergirding agriculture, mining and the entire industry value chain alongside native petty and comprador bourgeoisie elements (Mandaza, 1986; Moyo and Yeros, 2005).

Such a dual identity allowed the government to court international goodwill which was so critical not only for transitional stability but also for the government's image as walking the talk regarding the policy of racial reconciliation that the new administration had preached upon assuming the reins of power (Mandaza, 1986). This pacted transition to independence in Zimbabwe and latter in Namibia and South Africa birthed a "liberal-constitutional regime in which the metropole hand over political control but secure their economic interests through the promulgation of a constitution that enshrines property and human rights" (Alden and Anseeuw, 2009). Resultantly, land grievances and calls for restitution which had driven the liberation struggle were bargained at best for political and economic stability and masked or 
postponed at worst by the liberal constitutional provisions of property rights which were made inviolable through the 10-year moratorium on land expropriation. In the end, there was a yawning gap between the government's initial rhetoric on land redistribution and the actual policy inertia which was a result of institutional constraints.

During the first decade in post-independence Zimbabwe land redistribution was stymied, constrained or postponed at worst. The journey towards land redistribution was never going to be a proverbial victory march to Havana by Fidel Castro after the fall of Fulgencio Batista in 1959 as would have been idealized by the liberation ideals and euphoria of independence, one with the notoriety to promote the rhetoric of 'driving the colonizer to the seas'. Lancaster House negotiations and the harsh reality of governance and statecraft in contradistinction to the command of a revolutionary movement had its unique demands which expunged the lofty rhetoric of land expropriation and redistribution. Thus, landed elites can protect their interests even under a democracy by forging elite based pacts during the transition which creates favorable democratic values that entrench the elite status quo (Snyder and Samuels, 2004). In Zimbabwe's particular case, the Sunset Clauses at the Lancaster negotiations proscribed the prospects of land expropriation and redistribution through the 10-year moratorium that protected the sanctity of land property rights for the first 10 years of independence and the imposition of a Willing Buyer Willing Seller principle (WBWS) whose traction was negligible.

The first decade of Zimbabwe's post-independence transition projected a conflicted identity one borne out of the contradictions of serving the disparate demands of mutually incompatible elements forming the initial and governing coalitions. However, it is also important to take stock of the structural contradictions obtaining in Zimbabwe during the early years of independence which manifested through conflicts not only between the aspiring black bourgeoisie and established capital but also within the rank and file of the ruling political elite. Resultantly, this led to the instrumentalization of land policy, ethnicity and violence of which the Gukurahundi disturbances (1983-1987) can be viewed through such lenses (Moyo and Yeros, 2005; Mandaza, 1986; Raftopoulos, 1992). Several studies posit the paradoxes of state compradorization, avaricious accumulation and the growth of an entrenched patronage network which could have diverted attention and slowed the pace of land redistribution during the first decade of independence (Bond, 1998; Ndlovu-Gatsheni, 2015). These various contradictions point to the shortcomings of Albertus' theory in that they unravel the fact that the success or failure of redistribution can be a function of other factors that may be divorced from the regime type or governance systems but rather systemic issues which in this case were competing with the land issue for elite attention (Thatcher, 1980; Dzimba, 1998; Mandaza, 1986a).

In view of the aforesaid, it can be inferred that land expropriation and redistribution may be difficult to promote under democracy because of the presence of multiple vested interests that find expression in different institutions. Hence, the argument by Ziblatt (2009) and Albertus (2015), that elites wield so much influence and mechanisms of power that can derail plans for land redistribution. International economic interests through the Lancaster House agreement managed to factionalize and fractionalize the power inherent in the initial coalition between 
the ruling elites and the peasantry which resulted in land redistribution being sacrificed on the altar of political expediency (Alden and Anseeuw, 2009). On the contrary, it is widely acknowledged that although policy traction was somehow negligible and official targets were not fulfilled, land redistribution was not a failure in the 1980s. While the Willing-Buyer Willing-Seller mechanism failed to meet the expectations of the new administration given that very few farmers were willing to sell their land, significant redistribution was realized and the process was somehow more orderly not only in the change of proprietorship but in the provision of inputs, extension services, marketing structures and other community infrastructure deliverables and support systems (Matondi, 2012).

\subsection{Elite Splits and Redistribution}

Traditionally, ruling elites have the control and capability to run a government through a legitimate monopoly on the apparatus of violence which implies that landed elites always find it difficult to hem the actions of the ruling elite (Albertus, 2015). Land expropriation and redistribution can be a result of elite splits between the ruling and the landed elites or within the ruling elite which creates push factors for redistributions to be implemented. Elite splits can be a result of ethnic fractionalization whereby land is vested in the hands of the minority which fuels political out-group apprehension (Albetus, 2015). Sociology has grappled with the concept of out-group and in-group culture, the creation of values, obligations, and identities binding group members and how these factors create contours of difference and shape intergroup perceptions and interactions (Chen and Li, 2009; Habyarimana, 2007). Zimbabwe depicts this analogy, not in an ethnic sense but some racial configuration wherein a white minority not only had proprietorship of land, but also entrenched privileges determining access and control of the commanding heights of the economy. Resultantly, the native was dispossessed of his land, structurally marginalized, racially 'Othered' and made invisible (Hughes, 2006). Colonial 'governmentality' and its mechanics of power proscribed native social, political and economic mobility and its mechanics of power was heavily reliant on violence to maintain the social stratification or racial compartmentalization (Mbembe, 2001)

Unlike the neo Europes in the Antipodes or the Americas (now the United States of America) where native populations were systematically crowded out and whites became the majority, in Zimbabwe, the white population remained a tiny minority (approximately between $1-3 \%$ of the population) by 1980 controlling two-thirds of national income (Moyo, 1995; Hughes, 2006). Such "an obdurate minority of white Large Scale Commercial Farmers LSCF largely of British descent, brought up and sustained by British colonialism" (Robert Mugabe, 2001), resultantly created an out-group apprehension within the native enclave emanating from the unequal social relationship. The ruling coalition was systematically denied any real prospects of social, political and economic mobility primarily because of their skin color (Gellner, 1983). However, it is imperative to critique the veracity of the agency of racial apprehension towards land redistribution. While the shadow of colonial residue cannot be underestimated, the credence of racial animus 20 years after independence has been contested and debased by other scholars who noted that land was a long held historic fault line, the longer it took without being resolved, the more it became potential fodder for populism and political 
aggrandizement schemes (Laurie, 2016).

The agency of elite splits as a driver of land redistribution manifests itself in different configurations. The split could be attributed to party class based struggles between the elites and the war veterans long deemed to be the foot soldiers of the party who felt neglected and who economic and material wellbeing had taken a nosedive in the mid 1990s (Meredeth, 2002; Alexander and McGregor, 2013; Laurie, 2016). Thus, land redistribution could have been as a result of the elite bulking under pressure from within the party. In addition, elite fissures between the ruling elite and white capital could have been fuelled by the subsequent withdrawal of funding, mainly by the British government who cited misuse of funds, the elitist nature of land redistribution and most importantly the denial by the new Labour Government of any obligations to bankroll commitments made by the former Conservative regime in England (AAPPG, 2009). Furthermore, the schism between the governing elite and the white commercial farmers could have been fuelled by the latter's obstinacy to land redistribution either through litigations or various on-the-farm investments which they hoped could hedge their proprietorship of the land through the raising of the cost of compensation beyond the economic capability of the government especially after the expiry of the 10 year moratorium on land expropriation and redistribution as set out by the Lancaster House Agreement (Hughes, 2006). Hence, it is factual to allude that, land redistribution at the turn of the millennia was a consequence of elite splits that found expression at various fronts.

\subsection{State Autonomy, Economic Diversification, and Elite Splits}

The relationship between the state and capital can be one of collusion where the former acts as an agency of the dominant economic class creating structural dependence (Hellman, 2003). The issue of structural dependence between the state and capital is deemed to be a straight jacket regardless of who is in power, the nature of their coalition or the organization of the state whether autocratic or democratic. However, besides promoting the interests of economic elites, the state has other equally important duties which include administrative, extractive and coercive functions that are distinctly autonomous from the vested interests of various social groupings (Skocpol, 1985). The tension between the regime and economic interests can result in an elite split that incentives redistribution like in Peru between 1968 and 1980 under the military junta of Generals Juan Velasco Alvarez and Francis Morales Bermudez. The military junta in Peru had been manipulated by the landed elites who regulated their budgets operations and directed state policy due to their economic strengths. The military sought to "break the back of the oligarchy" (Albertus, 2011: 47) hence they expropriated and redistributed 15000 landholdings which were approximately $45 \%$ of agricultural arable land in Peru. While most of the beneficiaries were the poor, this program allowed the military junta to consolidate in power. This redistribution transformed agrarian relations in Peru, abolished peonage, decimated the minifundio-hacienda-encomienda axis of evil becoming a "momentous shift in the history of the Andes akin to the abolition of slavery in the Americas" (Mayer, 2009:6).

A major cause of the "divergence between the ruling political elites and landed elites is a developing economy in which other sectors compete with or displace the primacy of 
agriculture" (Albertus, 2015: 54). The diversification of the industry creates new actors like industrial elites and the working middle class which can fundamentally result in a restructuring of coalitional dynamics between the ruling and landed elites where conflicting interests between landed elites and the new actors abound (Ansell and Samuels, 2010). The primacy of agriculture in most post-settler economies as the mainstay of the economy is not unusual. The development thrust of the 1980s focused at restructuring an economy whose pattern of accumulation remained starkly disarticulated, dominated by agriculture and wherein the home market crowded a significant chunk of the population by restricting itself to only $15 \%$ of a total population of 7 million then (Moyo and Yeros, 2005).

These demands for petty black capitalist embourgeoisement soon after independence were typical of 'it is our time to eat' syndrome. And the need for economic diversification was partly responsible for driving the ruling elites on a collision course with the landed elites. Therefore the friction between black aspirations for embourgeoisement and white capital's preservation of the status quo ante, laid the foundation for the development of a large schism between the ruling and landed elites. According to Moyo and Yeros (2005), the petty black bourgeoisie was effectively crowded out of the white-dominated private sector hence they resorted to the state as the most viable agency of accumulation. International capital was always skeptical about the new government's Marxist-Leninist rhetoric and African nationalism in general despite the government's pretensions on 'Growth with Equity' policy. Through the International Monetary Fund IMF and its debt politics, the government was reined in and its economic policies form then own subject to dictates (Moyo and Yeros, 2005). While the advice was fiscally prudent, it had the undesired effect of creating an aspiration gap on those who were previously disadvantaged and who expected various forms of restitution.

Therefore, while it is conveniently prudent to scapegoat the IMF and World Bank (WB) because of their neo-liberal cloak, Zimbabwe's fiscal health was not promising, with balance of payment arrears rising exponentially in the post independence era. This was partly because of excessive borrowing, the effects of the 1982 drought and the heavy spending on Defense which was necessitated by the fragile security scenario immediately after independence attributed to the counter-reactionary efforts of Apartheid South Africa and the internal disturbances in Zimbabwe (Stoneman and Cliffe, 1989; Dzimba; 1998)

\subsection{Concentration of Power and Redistribution}

Autocracies, authoritarian or in this case hybrid regimes or single party systems project low institutional constraints that tend to encourage an expeditious implementation of land reform (Albertus, 2015). Land expropriation and redistribution involve the physical transfer of land from concentrated powerful landed elites with strong collective action which makes policy traction a very protracted undertaking compared to other forms of land reform like land negotiation and colonization. Unlike democracies in which institutional gridlock is very high, autocratic institutions are dominated by a loyal clique of ruling elites whose allegiance and existence revolves around a powerful figure, dictator or junta (Bueno de Mesquita, 2003). Single party regimes bank on strong state apparatus whose coordination is critical for implementation. Along the continuum, legislative, judicial and bureaucratic functions are not 
only compromised but also conditioned along with ethnic loyalties and partisan lines (Albertus and Menaldo, 2012; Svolik, 2009; Olsson, 1993). Hence, the proposition that land expropriation and redistribution is more likely to be executed under an autocracy than a democracy (Albertus, 2015).

Zimbabwe inherited a parliamentary system at independence with an Executive Prime Minister and Ceremonial President. Robert Mugabe's Zimbabwe African National Union (ZANU) won the inaugural elections with him becoming the first post-independence Prime Minister of Zimbabwe in 1980. The 1980s witnessed internal elite feuding between ZANU and the Zimbabwe African People's Union (ZAPU), the origins of which are not part of the paper, suffice to state that the elite differences left the country on the brink of internal implosion (Sithole and Makumbe, 1997; Power, 2003). The 1987 Unity Accord Agreement was signed ending hostilities and merging ZANU and ZAPU into ZANU PF (Zimbabwe African National Union-Patriotic Front). The same Agreement dissolved the Executive Prime Minister's post and replaced it with an Executive Presidency. Zimbabwe became a de facto one-party state in with ZANU PF becoming a monolithic hegemony in the subsequent plebiscites and the power became increasingly concentrated in the Presidium (Ndlovu Gatsheni, 2011).

Even when political opposition became very competitive with the formation of the Movement for Democratic Change in 1999, the ruling party remained dominant albeit on contested terms (Coltart, 2016). Zimbabwe can be termed a hybrid regime in which multipartyism is practiced however because of the concentration of power, ruling elites retain control of the extent of political opening and can resort to unorthodox ways to retain power, of which violence is always within easy reach (Le Bas, 2011). The sanctity of the protected consultation as a measure of democracy is not honored (Tilly, 2004a). Opposition politics in these regimes is mainly driven by the need for transparency, respect for human rights and a myriad of reforms to promote access to a seemingly crowded out political space (Gwekwerere and Mpondi, 2018), and most importantly, "a tolerant, competent and consulting state in which power is accountable to its citizens” (MDC Alliance Manifesto, 2018: 3)

Potential institutional setbacks were circumvented in which the legislature, judiciary, and bureaucracy were systematically undercut with their oversight role and veto gauntlet capability reigned in (Albertus, 2015). The legislative and oversight role of Parliament was overridden by the fact that ZANU PF still commanded a majority in the House and it was a matter of 'whipping' party representatives in the August house. The major stumbling block to expropriation was the Judiciary which had a considerable white bench (Laurie, 2016; Meredeth, 2002) which in many instances ruled against the invasions sighting the incursion on private property rights and the requirement to compensate the disposed of landowners. The then President of Zimbabwe stated that, "the courts can do whatever they want, but no judicial decision will stand in our way. They are not courts for our people and we shall not even be defending ourselves in these courts" (Mugabe, 2001). Through the Presidential Powers Act, the various amendment was also made to the Land Acquisition Act (2000) which effectively constrained the efficiency of the courts, either by slowing the due process, postponing compensation or liquidation of other institutional stumbling blocks to 
expropriation (Laurie, 2016). Because the institutional autonomy the judiciary was stymied and the fact that Parliament could be whipped in line easily because of ZANU PF's majority membership, the Rural Land Occupiers (Protection from Eviction) Act of 2001 was passed which effectively protected the land invaders from any lawsuits.

The execution of land expropriation projected signs of chaos, confusion and lack of planning concerning how marauding war veterans and associated paramilitary bands invaded farms but this should not be conflated with a lack of institutional unity of purpose (Matondi, 2012, Laurie, 2016). The Fast Track Land Reform Program (FTLRP) as it was affectionately termed was executed through systematic coordination both at micro and macro levels between government structures and ZANU PF party structures. The war veterans' umbrella body the Zimbabwe National Liberation War Veterans Association (ZNLWVA) was also actively involved and its structures from the grassroots to the national level were also heavily activated. Besides, law enforcement personnel were involved in logistical support and enforcement in case of resistance from the white farmers. Therefore, the ruling elite successfully managed to pacify any potential institutional setback which gives credence to the proposition by Albertus (2015), that land redistribution has a high chance of implementation in regimes with a higher concentration of power which project low institutional constraints.

\section{Post Cold War Dynamics}

While there is a correlation between hybrid regimes which exhibit a higher degree of power centralization and the probability of land expropriation and redistribution, the aspect of causality between the two variables is somehow ambiguous. The gradual shift from state-led development in the 1980s to neo-liberalism in the (1990s) and the adoption of austerity policies had far-reaching consequences. The collapse of the Union of Soviet Socialist Republics (USSR) as an 'external power' put many African countries into a situation of 'fractured sovereignty' wherein the tutelary government of the Bretton Woods institutions cobwebbed economic management, credit control, privatizations, superintended policies on import, consumption and fiscal regimes (Mbembe, 2001). The dominant narrative of the late 80s argued that state dirigisme was the main cause of economic malaise in Africa; therefore the panacea was premised on the State's retraction from welfarism and obligations to society (Bond \& Manyanya, 2002; Phimister \& Raftopoulos, 2004).

The retraction of the State from welfarism meant that the 1990s decade witnessed the genesis of a socio-economic and political quagmire whereby the state, "was unable to make necessary decisions on who is to get what and to determine the social compromises vital...not only to a market economy....but also to the very production of public order" (Mbembe, 2001). Thus the 1990s promise of the Economic Structural Adjustment Program (ESAP) turned out to be a utopia in Zimbabwe and elsewhere across the continent; austerity brought no restructuring, no integration into the world economy, but rather opened a Pandora's box of disorder and militancy in trade unionism as the disenfranchised working-class fought the economic and material depredations, loss of jobs, inflation and a rising cost of living amid the erosion of social safety nets. Also, there was a potential transition to liberal democracy and market economy or a slide into civil disorder and chaos or state dirigisme as the state maneuvered to 
recoup lost ground and legitimacy.

The attendant waves of currency speculation, raiding of foreign reserves, domestic credit crunches and stock market panic signified the general economic malaise. Agriculture was not spared as it suffered from the economic liberalization and the general retreat of the state from controlling staple and other agricultural commodities and its welfarist obligations (Moyo, 2011). The adoption of the dirigiste methods of economic management and agrarian radicalism, the concomitant international condemnation, withdrawal of lines of credit and the imposition of economic sanctions can be best understood through the prism of the 1990s social, political and economic morass.

Therefore the 1990s were an era of acute shortage and want, an era characterized by an erosion of working-class wage earnings, rising inflation and cost of living, increasing confrontation between the State and trade unionism, an epoch witnessing the restructuring of the political community along with class struggles and the associated privileges to patronage and perks; hence calls for affirmative action either through land redistribution or indigenous empowerment initiatives grew louder. The retraction of the State opened the floodgates for accumulation and black embourgeoisement otherwise known as the indigenization drive which resulted in contestations over, "the redistribution over the means of livelihoods and perks-allocation of credit, awarding of public contracts, infrastructure projects...." (Mbembe, 2001). The black business lobby sought preferential government action as a stimulus to the development of a black capitalist class.

Given the foregoing, land expropriation and redistribution in Zimbabwe may not have been as a result of the regime type per se but rather as a consequence of other variables. It is widely acknowledged that state predations played a huge role in determining the nature and inertia of land expropriation but so were other factors both domestic and international outside the purview of governance. On the one hand, there is a hybrid regime or what other scholars have termed as an authoritarian regime whose predations and excesses are widely reported (Blair, 2002; Meredeth, 2002; Ndlovu Gatsheni, 2011). On the other hand, is the huge role that international capital (Bond, 1998), former colonial power (Dube, 2019), commercial white farmer intransigence and exceptionalism (Fisher, 2010; Hughes, 2006) and most importantly class struggles within the revolutionary movement between the elite and veterans of the struggle all of which combined towards the fast track land redistribution.

In a post-Cold War neo-liberal order in which sovereignty has become fluid and the connectography of the international political economy has become more integrated, state dirigisme or the radical economic policies that disregard the protected consultation can be highly counterproductive. The contemporary globalized political economy imposes a lot of constraints and sanctions serious repercussions against any violation of its sacrosanct values like the inviolability of property rights, good governance, respect for the rule of law and so forth. The ambivalent response to land redistribution from within Namibia and South Africa, two countries with an identical settler heritage, wherein independence came through pacted arrangements explains this factor (Alden and Anseeuw, 2009). Their liberal constitutional regimes born out of the independence negotiations provides legal obstacles while the 
international capitalist political economy and its values act as a deterrent through assured sanctioning, cutting off lines of credit or international isolation just as the Zimbabwean case exemplifies. Hence land redistribution that muzzles the agency of institutional autonomy and veto gauntlet can be highly problematic in the post-cold war era characterized by a globalized political economy.

\subsection{Power, Patronage, Populism, and Redistribution}

The narrative that autocracies implement land redistribution specifically to quell internal threats to their power from both inside and outside their coalition is widely shared (Svolik, 2009; Geddes, 2003; Haber, 2006). For example through the Presidential Decree 27 of 1971, Ferdinand Marcos implemented land expropriation and redistribution at a time when his political legitimacy was under threat (Powelson and Stock, 1990). Just like ZANU PF which campaigned under the slogan the 'Land is the Economy'; Marcos intimated that land redistribution was for "the emancipation of the tiller from the bondage of the soil" in his New Society rhetoric (Powelson and Stock, 1990:16). In the case of Zimbabwe, there is a narrative that the government hastily implemented the land redistribution in a desperate attempt to pacify the threat to ruling elites emanating for the war veterans (Laurie, 2016). The land was seen as appropriate fodder to placate the grassroots and as patronage booty to peasant dependencies and disparate constituencies with the potential to fuel grassroots discontent and even upheaval. It is a fact, war veterans had become disillusioned and disgruntled about the slow pace of land reform with most of them wallowing in poverty. Their disgruntlement was a potential threat to the party's internal cohesion, legitimacy and even political survival.

Land expropriation and redistribution are also viewed as a cunningly designed political move to regain political ground at a time when the ruling elites faced a serious threat to their legitimacy by the opposition Movement for Democratic Change Party (MDC). The first opposition political party to seriously challenge ZANU PF's dominance was formed in 1999. The MDC party was a conglomeration of trade unions, residents associations, civic groups and pressure groups that merged with the giant Zimbabwe Congress of Trade Unions (Le Bas, 2011). From a corporatized formation during the early years of independence, trade unionism transformed itself in the 1990s against the background of socio-economic rupture increasingly became militant and later morphed into the fully-fledged political outfit. The new party jolted ZANU PF with a coordination of the NO vote in the rejection of the constitutional proposals and also in scooping 57 seats in the 2000 parliamentary elections (Meredeth, 2002; Blair, 2002; Sachikonye, 2005) This was the first time in the history of independent Zimbabwe that an opposition party had gained so much ground and threatened ZANU PF's hegemony. Hence, it has been argued that land reform was an attempt by the ruling elites to appease domestic populism and to divert people's attention from the pitfalls of economic matters that had eroded the citizenry's material wellbeing (Melber, 2015).

Besides, land redistribution in much of the developing world has benefitted the state or the elites who have enriched themselves as opposed to the peasants or the poor (Powelson and Stock, 1990). While land redistribution remains a proven means of promoting equity, how it has been implemented in many instances does not guarantee social transformation. According 
to Powelson and Stock (1990), most land redistribution in most developing countries has been by 'grace not by 'leverage'. Redistribution by grace is initiated by the elites while redistribution by leverage is initiated by the peasants from the grassroots. Therefore, in most cases redistribution by 'grace' is tainted by elitist, partisan and political undertones which may severely undercut and condition access by some segments of the society and those without political capital or outside the patron-client network. Hence, the allegations which to some extend are substantial, that most of the beneficiaries of the land redistribution were ZANU PF supporters. While Zimbabwe's redistribution has got traits of 'leverage' and 'grace' it was more of a movement whose agency owes much to 'grace' not leverage. It is worthwhile to note that unlike the case in Latin America where there is a vigorous and powerful lobby drive by the Non Governmental Organisations (NGOs), and other private stakeholders, rural societies in most of the Southern African former settler colonies are still hamstrung by institutional structures like the traditional chieftaincy and powerful party systems that create contours guiding and parameters around the rural economy.

Pursuant therefore, land redistribution can be another cunning plan by political elites to fixate rural populations or other constituencies of strategic importance to specific areas where they can gain access to new political trinkets that can further entrench dependency on the state (Albertus, 2015). The study notes that land redistribution is a highly contested exercise because of its propensity to restructure not only the ownership and creation of wealth but also its ability to reduce the cost of the ruling by creating constituent dependencies that are vital for political capital. Programs like the Presidential Input Support Schemes, Operation Maguta or lately Command Agriculture could be viewed as a political hedge in entrenching regime support and legitimacy. This is without overlooking the vital role that these programs continue to play in supporting resettled farmers to be productive in a very constrained and volatile macroeconomic environment.

On the contrary, it is important to reflect that as long as the land discourse in southern Africa is historically rooted in colonial injustices and driven by notions of restitution coupled by the limits of democratic constitutionalism to substantively address colonial residue of structural inequalities in the post-colonial political economy (Alden and Anseeuw, 2009), redistribution from the top remains very attractive. Needless to mention that the land discourse in most post-colonies intimates the misgivings and condescending character of international capitalism in circumscribing African progress to that of merely being "hewers of developmental wood and fetchers of growth water" (Kieh, 2018). Despite the detestable aspects of state excesses and other unsavoury predatory practices by the elites which remain as some of the unpalatable realities of redistribution from the top, this article argues that the agency of dirigisme on land expropriation and redistribution in post colonies remains strong. In such circumstances, therefore, a kind of 'double movements' perspective (Polanyi, 1954) becomes essential wherein efforts should be directed at addressing the imperfections that abound as a result of the initial redistribution in a bid to make land redistribution a proper means to the end. On this aspect, Zimbabwe's experience is not encouraging nevertheless; progress has been made to rationalize land administration, support mechanisms and so forth, even though issues of tenure, multiple farm ownership, and imperfect markets remain 
outstanding.

It is crucial to highlight that land reform was revolutionary and a necessary step that should not be relegated as a malicious exercise designed for political expediency. To do so would be tantamount to ignoring the enormous structural transformations of removing deep-seated legacies of colonial injustices and giving proprietorship of land to the hitherto marginalized cohorts. This assertion is mindful of the manner that Zimbabwe's land redistribution was implemented, the violence, nepotism and the general Machiavellian atmosphere engulfing the exercise which this article does not only condone but find detestable. However, be that as it may, land expropriation was transformational and it reordered social relations of power and affluence despite the attendant administrative and institutional deficiencies (Lipton, 2009). It can be argued that land redistribution under democracy has more likelihood of benefitting the poor. However, most post-colonial states with a settler heritage where independence came through pacted arrangements have a terrible memory with transitional liberal constitutions whose main thrust was the protection of international capital at the detriment of redistribution. Zimbabwe's trajectory offers a useful frame of reference of the contradictions between redistribution by 'grace' and redistribution by leverage against a complicated historical setting and post-colonial contemporary complexities.

\section{Conclusion}

Land expropriation and redistribution is very fundamental because of its ability to execute the physical transfer of land from the landed elites to the poor thereby reordering social relationships of power, pride, wealth and affluence. Because of its affirmative action appeal, land expropriations and redistribution became and remains the vanguard of land reform in much of the post colonies from South America to Africa where colonialism created severe inequalities. Extant literature, therefore, has struggled to provide answers on the nature of political conditions necessary for reform to take place, why governments engage in socially redistributive land reform and to unravel the incentives that encourage reforms. The relationship between the type of government and redistribution becomes critical. Theoretical contestations have dominated the discourse of land reform ranging from the proposition that land redistribution happens most likely under democracies to the proposition that autocracies remove the veto gauntlet, therefore, increasing the probability of redistribution.

The Zimbabwean narrative acts as a referent point by giving contours on the analysis of Albertus's theory that land reform happens more often under an autocracy than under a democracy. According to Albertus (2015), the concentration of power and absence of institutional autonomy in autocracies or hybrid regimes implies that there are no constraints to stymie land redistribution than under democracies which are replete with checks and balances that encourage veto gauntlet. Zimbabwean discourse proves that institutional autonomy can hem prospects for land redistribution. Events during the late 1990s towards the turn of millennia signaled a dramatic shift in land redistribution whereby, the ruling elites circumvented institutional autonomy and proceeded to expedite land redistribution. The study also endeavored to highlight some of the contradictions posed by the post-cold war era in which sovereignty has been fractured and how the attendant political economy can proscribe 
redistribution that does not adhere to its values and dictates. In the same vein, the paper went on to discuss how redistribution from the top is fraught with elitist and partisan undertones that can undercut the agency of land redistribution as a vehicle for social equity and socio-economic mobility. These various strands of arguments that dominate the Zimbabwean land discourse provide illuminating views vital to an analysis of Albertus' theory to the effect that land reform is encouraged under autocracies than under a democracy.

\section{Endnotes}

1. Gukurahundi (the early rain which washes away the chaff before the spring rains) refers to some post-independence civil disturbances in the Midlands and South Western parts of Zimbabwe caused by allegations of dissident activities by PF ZAPU's former guerilla fighters. This refers to a crackdown by the Zimbabwe National Army in those parts of the country from 1983 to 1987.

\section{Acknowledgements}

The author is very grateful for the guidance rendered by Professor Lin Ye of the School of Government, Sun Yat Sen University during the authorship of this Article.

\section{References}

Africa All Party Parliamentary Group Report. (2009). London, UK. House of Commons.

Acemoglu, D., \& Robinson, J. (2006). Economic Origins of Dictatorship and Democracy. Cambridge. Cambridge University Press. https://doi.org/10.1017/CBO9780511510809

Albertus, M., \& Menaldo, V. (2012). If you're against them you're with us: The effect of expropriation on autocratic survival. Comparative Political Studies, 45(8), 973-1003. https://doi.org/10.1177/0010414011428593

Albertus, M. (2015). Autocracy and redistribution . Cambridge University Press. https://doi.org/10.1017/CBO9781316227107

Alden, P., \& Makumbe, J. (2001). The Zimbabwe constitution: race, land reform and social justice. Global Multiculturalism, Rowman and Littlefield, United States of America, 215-37.

Alden, C., \& Anseeuw, W. (2009). Land, liberation and compromise in Southern Africa. Springer. https://doi.org/10.1057/9780230250970

Alexander, J., \& McGregor, J. (2013). Introduction: Politics, patronage and violence in Zimbabwe. https://doi.org/10.1080/03057070.2013.862100

Aristotle. (1992). The Politics. Transalated by Sinclair, T, A. Edited by Saunders, T. London: Penguin Books.

Barraclough, S., \& Collarte, J. C. (1973). Agrarian Structure in Latin America: A Resume of the CIDA Land Tenure Studies Of: Argentina, Brazil, Chile, Colombia, Ecuador, Guatemala, Peru . Lexington, MA: Lexington Books.

Bernstein, H., \& Byres, T. J. (2001). From peasant studies to agrarian change. Journal of agrarian change, 1(1), 1-56. https://doi.org/10.1111/1471-0366.00002 
Blair, D. (2002). Degrees in Violence. Robert Mugabe and the Strugglefor Power in Zimbabwe, Boix, C. (2003). Democracy and Redistribution. Cambridge: Cambridge University Press.

Bond, P. (1998). Uneven Zimbabwe: a study of finance, development, and underdevelopment . Africa World Press.

Bond, P., \& Manyanya, M. (2002). Zimbabwe's plunge. Exhausted Nationalism, Neoliberalsm and the search for Social Justice 2nd Edition: University of Natal Press, Pietersburg.

De Mesquita, B. B., Smith, A., Siverson, R. M., \& Morrow, J. D. (2005). The logic of political survival. MIT press.

Chen, Y., \& Li, S, X. (2009). Group Identiry and Social Preferences. American Economic Review, 99 (1), 431-457. https://doi.org/10.1257/aer.99.1.431

Clapham, C. (2012). From Liberation Movement to Government: Past Legacies and the Challenges of Transition in Africa. The Brenthurst Foundation Discussion Paper, 8, 2012.

Coltart, D. (2016). The Struggle Continues: 50 Years of Tyranny in Zimbabwe. Jacana Media (Pty) Ltd, South Africa.

Deininger, K. (2003). Land Policies for Growth and Poverty Reduction.” Washington, DC: World Bank.

De Villiers, B. (2003). Land Reform. Issues and Challenges: A Comparative Overview of Experiences in Zimbabwe, Namibia, South Africa AND Australia. Johannesburg: Konrad Adenauer Foundation.

Dube, M., \& Midgely, R. (2008). "Land Reform in Zimbabwe: Context, Process, Legal and Constitutional Issues and Implications for SADC Region." In Bosl, A. et al, eds. Monitoring Regional Integration in Southern Africa Yearbook, vol. 8, 303-341. Stellenbosch: Trade Law Centre for Southern Africa.

Dube, L. M. (2019). Restitution versus Populism: Revisiting the Dominant Tropes of the Land Question in Zimbabwe. Open Journal of Social Sciences, 7, 203-219. https://doi.org/10.4236/jss.2019.710017

Dzimba, J. (1998). “South Africa's Destabilization of Zimbabwe”, 1980-89. St Martin's Press, Inc., NY. https://doi.org/10.1057/9780230372146

Fisher, J. L. (2010). Pioneers, Settlers, Aliens, Exiles: The Decolonisation of White Identity in Zimbabwe. Canberra, Australia. Australia National University Press. https://doi.org/10.26530/OAPEN_459443

Geddes, B. (2003). Paradigms and Sand Castles. Ann Arbor: University of Michigan Press. https://doi.org/10.3998/mpub.11910

Gellner, E. (1983). Nationa and Nationalism. Ithaca, NY Cornell University Press.

Gwekwerere, T., \& Mpondi, D. (2018). Memory, Identity and Power in Contemporary 
Zimbabwe: Movement for Democratic Change Electoral Narratives and Zimbabwe African Union-Patriotic Front Counter-Discourse. Africology: The Journal of Pan African Studies, vol. 12 , no.3.

Haber, S. (2006). Authoritarian Government. In Barry Weingast and Donald Wittman, eds, The Oxford Handbook of Political Economy, 693-707. Oxford. Oxford University Press.

Habyarimana, J., Humphreys, M., Posner, D. N., \& Weinstein, J. M. (2007). Why does ethnic diversity undermine public goods provision?. American Political Science Review, 101(4), 709-725. https://doi.org/10.1017/S0003055407070499

Hellman, J. S., Jones, G., \& Kaufmann, D. (2003). Seize the state, seize the day: state capture and influence in transition economies. Journal of comparative economics, 31(4), 751-773. https://doi.org/10.1016/j.jce.2003.09.006

Huntington, S. (1968). Political order in changing societies New Haven: Yale U.

Iverson, T., \& Soskice, D. (2009). Electoral Systems and the Politics of Coalitions. American Political Science Review, 100(2), 161-181.

Kanyenze, G. (1996). “Labour Markets and Employment During ESAP.” Mimeo.

Karl, T. (1990). Dilemmas of Democratization in Latin America. Comparative Politics, 23, 1-21. https://doi.org/10.2307/422302

Kieh, G. K. (2018). The Elusive African Rennaisance: Essays on Today's Critical Development Issues. North Carolina: McFarland University Press

Lapp, N. (2004). Landing Votes: Representation and Land Reform in Latin America. New York. Palgrave Macmillan. https://doi.org/10.1057/9781403976819

Laurie, A. C. (2016). The Land Reform Deception: Political Opportunism in Zimbabwe's Land Seizure Era. Oxford University Press. https://doi.org/10.1093/acprof:oso/9780199398294.001.0001

Le Bas, A. (2011). From Protest to Parties: Party Building and Democratization in Africa. Oxford: Oxford University Press. https://doi.org/10.1093/acprof:oso/9780199546862.001.0001

Levine, R. (1998). Father of the Poor? Vargas and His Era. Cambridge: Cambridge University Press.

Lipton, M. (2009). Land Reform in Developing Countries: Property Rights and Property Wrongs. New York: Routledge. https://doi.org/10.4324/9780203876251

Mandaza, I. (1986a). The Political Economy of Transition in Zimbabwe: In the Political Economy of Transition, 1980-1986, eds. Mandaza, I, Dakar: CODESRIA.

Matondi, P. B. (2012). Zimbabwe's fast track land reform. Zed Books Ltd.

Mayer, E. (2009). Ugly stories of the Peruvian agrarian reform. Duke University Press. https://doi.org/10.1215/9780822390718 
Mbembe, A. (2001). On the postcolony (Vol. 41). Univ of California Press.

McDermot Hughes, D. (2006). Whiteness in Zimbabwe: Race, Landscape and the Problem of Belonging. New York. Palgrave Macmillan.

MDC Department of Information and Publicity. (2018). MDC manifesto. Harare.

Melber, H. (2015). In the Footsteps of Robert Gabriel Mugabe: Namibian Solidarity with Mugabe's Populism - (Bogus) Anti-imperialism in Practice. In Mugabeism? (pp. 107-120). Palgrave Macmillan, New York. https://doi.org/10.1057/9781137543462_7

Meltzer, A. H., \& Richard, S. F. (1981). A rational theory of the size of government. Journal of political Economy, 89(5), 914-927. https://doi.org/10.1086/261013

Meredith, M. (2002). Robert Mugabe. Power and Plunder in Zimbabwe, London: Public Affairs.

Moyo, S. (1995). The Land Question in Zimbabwe, Harare: SAPES Books.

Moyo, S., \& Yeros, P. (Eds.) (2005a). Reclaiming Land: The Resurgence of Rural Movements in Africa, Asia and Latin America. London: Zed Books.

Mulligan, C., Gil, R., \& Sala-i-Martin, X. (2004). Do Democracies have Different Public Policies than Nondemoracies? Journal of Economic Perspectives, 18(1), 51-74. https://doi.org/10.1257/089533004773563430

Ndlovu-Gatsheni, S. J. (2011, June). The construction and decline of Chimurenga monologue in Zimbabwe: A study in resilience of ideology and limits of alternatives. In Comparative Perspectives from East and Southern Africa at the 4th European Conference on African Studies (ECAS4) (pp. 1-22). https://doi.org/10.1093/acref/9780195301731.013.49596

Ndlovu-Gatsheni, S. J. (Eds) (2015). Mugabeism? History Politics and Power in Zimbabwe: African Histories and Modernities. Palgrave Macmillan. New York. https://doi.org/10.1057/9781137543462

North, D., \& Weingast, B. (1989). Constitutions and Commitments. Journal of Economic History, 49, 803-832. https://doi.org/10.1017/S0022050700009451

O’Donnell, G., \& Schmitter, P. (1986). Transitions from Authoritarian Rule. Baltimore: Johns Hopkins University Press.

Olson, M. (1993). Dictatorship, Democracy and Development. American Political Science Review, 87, 567-576.

Paige, J. (1975). Agrarian Revolution. New York: The Free Press.

Palmer, R. (1990). Land Reform in Zimbabwe. 1980-1990. African Affairs, 89, 163-181. https://doi.org/10.1093/oxfordjournals.afraf.a098283

Pazvakavambwa, S., \& Hungwe, V. (2009). "Land Redistribution in Zimbabwe." In Binswanger-Mkhize, H., Bourguignon, C and Van de Brink, J, E, R, eds. Agricultural Land Redistribution: Towards Greater Consensus on the "How," 137-168. Washington, DC: World 
Bank Publications.

Perotti, R. (1996). Growth, income distribution, and democracy: What the data say. Journal of Economic growth, 1(2), 149-187. https://doi.org/10.1007/BF00138861

Polanyi, K. (1954). The Great Transformation: The Political and Economic Origin of our Times. Boston: Beacon Press.

Powelson, J. P., \& Stock, R. (1990). The Peasant Betrayed: Agriculture and Land Reform in the Third World. CATO Institute, Washington DC.

Power, S. (2003). How to Kill a Country. The Atlantic.

Raftopoulos, B. (1992). Beyond the house of hunger: democratic struggle in Zimbabwe. Review of African Political Economy, 19(54), 59-74. https://doi.org/10.1080/03056249208703953

Raftopoulos, B., \& Phimister, I. (2004). Zimbabwe now: the political economy of crisis and coercion. Historical materialism, 12(4), 355-382. https://doi.org/10.1163/1569206043505301

Ranger, T. (2004). Nationalist historiography, patriotic history and the history of the nation: The struggle over the past in Zimbabwe. Journal of southern African studies, 30(2), 215-234. https://doi.org/10.1080/0305707042000215338

Raftopoulos, B. (1996). Fighting for control: The indigenization debate in Zimbabwe. Southern Africa Report, 11(4), 3-7.

Sachikonye, L. M. (2004). The promised land: From expropriation to reconciliation and Jambanja. Zimbabwe: Injustice and Political Reconciliation. Cape Town: Institute for Justice and Reconciliation, 1-18.

Schmitter, P. C. (2010). Democracy's Past and Future: Twenty-Five Years, Fifteen Findings. Journal of Democracy, 21(1), 17-28. https://doi.org/10.1353/jod.0.0144

Schmitter, P. (2010). Twenty Five Years, Fifteen Findings. Journal of Democracy, 21(1), 18-28. https://doi.org/10.1353/jod.0.0144

Sithole, M., \& Makumbe, J. (1997). Elections in Zimbabwe: The ZANU (PF) hegemony and its incipient decline. African Journal of Political Science/Revue Africaine de Science Politique, 122-139.

Skocpol, T. (1985). "Bringing the State Back In Strategies and Analysis in Current Research." In Evans, Rueschemeyer, D and Skocpol, T, eds. Bringing the State Back In, 3-37. Cambridge: Cambridge University Press. https://doi.org/10.1017/CBO9780511628283.002

Stoneman, C., \& Cliffe, L. (1989). Zimbabwe: Politics, Economics and Society. London; New York: Pinter Publishers.

Svolik, M. W. (2009). Power sharing and leadership dynamics in authoritarian regimes. American Journal of Political Science, 53(2), 477-494. https://doi.org/10.1111/j.1540-5907.2009.00382.x

Snyder, R., \& Samuels, D. (2004). Legislative Malapportionment in Latin America. In 


\section{Macrothink}

Journal of Public Administration and Governance ISSN 2161-7104 2020, Vol. 10, No. 2

Edward Gibson, ed., Federalism and Democracy in Latin America. Baltimore: Johns Hopkins University Press, pp. 131-172.

Tafira, C. K. (2015). Mugabe's Land Reform and the Provocation of Global White Anti Black Racism: In Ndlovu-Gatsheni, S. J. Mugabeism? : History, Politics, and Power in Zimbabwe, New York. Palgrave Macmillan.

Tai, H. C. (1974). Land Reform, and Politics. Berkeley: University of California Press.

Thatcher, G. (1980). Zimbabwe, South Africa Break Relations But Keep Trade Links. Christian Science Monitor, September 1985.

Thiesenhusen, W. (ed). (1989). Searching for Agrarian Reform in Latin America.

Tilly, C. (2004). Social Movements 1768-2004. New York. NY: Routledge.

Tsebelis, G. (2002). Veto Players. Princeton: Princeton University Press. https://doi.org/10.1515/9781400831456

Tuma, E. (1965). Twenty-Six Centuries of Agrarian Reform: A Comparative Analysis. Berkeley: University of California Press.

ZCTU. (1996). Beyond ESAP: Framework for a Long-TERM Development Strategy in Zimbabwe Beyond the Economic Structural Adjustment Programme, Harare: ZCTU.

Ziblatt, D. (2009). Shaping Democratic Practice and the Causes of Electoral Fraud: The Case of Nineteenth-Century Germany. American Political Science Review, 103(1), 1-21. https://doi.org/10.1017/S0003055409090042

\section{Copyright Disclaimer}

Copyright for this article is retained by the author(s), with first publication rights granted to the journal.

This is an open-access article distributed under the terms and conditions of the Creative Commons Attribution license (http://creativecommons.org/licenses/by/4.0/). 